\title{
ANALISIS HUKUM TERHADAP HAK-HAK ATAS TANAH SEBAGAI JAMINAN HUTANG DENGAN DIBEBANI HAK TANGGUNGAN
}

\author{
I Dewa Ayu Widyani ${ }^{1}$ \\ L. Elly AM Pandiangan
}

\begin{abstract}
The right on land as debt insurance be burdened by the right of burden as be mentioned in Article 51 only involve the right of ownership, the right of building usage. Because of the validation of the validation of laws about the right of burden as be arranged in Laws No. 4/1996, the right of usage is the right which is be registered and because its characteristics can be taken oven so that can be burdened by the right of burden. It is also can be done to the building on the land which is obligate to be registered and because its characteristics can be taken over so that can be burdened by the right of burden. Of course it is also to the building on land which different of its ownership whereas the principle of horizontal i of custom law, that become basic of UUPA, can be burdened by the right of burden.
\end{abstract}

\section{Kata Kunci:Hak-hak atas tanah yang dapat dibebani hak tanggungan.}

\section{PENDAHULUAN}

Pembangunan ekonomi adalah sebuah proses untuk menciptakan kesejahteraan umum dan mencerdaskan kehidupan bangsa, sebagaimana dirumuskan dalam Mukadimah Undang-Undang Dasar 1945.Dalam rangka pembangunan nasional pembangunan di bidang ekonomi merupakan salah satu upaya untuk mewujudkan masyarakat adil dan makmur berdasarkan Pancasila dan Undang-Undang Dasar 1945.

Untuk menjaga kesinambungan pembangunan tersebut, dibutuhkan penyediaan dana dalam jumlah yang cukup besar sehingga memerlukan lembaga hak jaminan yang kuat dan mampu memberikan perlindungan serta jaminan kepastian hukum bagi para pihak yang berkepentingan, baik pemberi atau penerima kredit serta pihak-pihak partisipasi masyarakat dalam pembangunan.

Jaminan merupakan sesuatu yang diberikan kepada kreditor untuk menimbulkan keyakinan bahwa debitor akan memenuhi kewajiban yang dapat dinilai dengan uang yang timbul dari suatu perikatan. ${ }^{2}$

\footnotetext{
${ }^{1}$ Dosen Tetap Fakultas Hukum UKI

${ }^{2}$ Salim HS, Perkembangan Hukum Jaminan di Indonesia,

Jakarta:PT. Raja Grafindo Persada, 2004, hal. 22.
}

Jaminan mempunyai kedudukan dan manfaat yang sangat penting dalam menunjang pembangunan ekonomi, karena keberadaan lembaga ini dapat memberikan manfaat bagi kreditur berupa terwujudnya keamanan terhadap transaksi dagang serta memberikan kepastian hukum bagi kreditur. ${ }^{3}$ Sementara bagi debitur dengan adanya benda jaminan dapat memperoleh fasilitas kredit dari bank dan tidak kwatir dalam mengembangkan usahanya, karena adanya kepastian dalam berusaha dengan modal yang diperolehnya.

Sebelum berlakunya Undang-Undang RI No. 4 tahun 1996 tentang Hak Tanggungan atas Tanah beserta Benda-Benda yang Berkaitan dengan Tanah (selanjutnya disebut hak tanggungan), peraturan perundang-undangan yang mengatur tentang pembebanan hak atas tanah adalah Pasal 21 Buku Kedua Kitab Undang-Undang Hukum Perdata (selanjutnya disebut KUH.Perdata), yang berkaitan dengan hipotek dan credietverband dalam staaatsblad 1908-542 sebagaimana telah diubah dengan staatsblad 1937190. Kedua ketentuan tersebut tidak berlaku lagi karena sudah tidak sesuai dengan kebutuhan kegiatan perkreditan di Indonesia.

\footnotetext{
${ }^{3}$ Sri Soedewi Masjhoen Sofwan, Hukum Jaminan di Indonesia Pokok-pokok Hukum dan Jaminan Perorangan, Jakarta : BPHN Departemen Kehakiman RI, 1980, Hal. 2
} 
St. Remy Sjahdeni mengatakan bahwa ketentuan tentang hipotek dan Credietverband itu tidak sesuai lagi dengan azas-azas hukum tanah nasional dan dalam kenyataannya tidak dapat menampung perkembangan yang terjadi dalam bidang perkreditan dan hak jaminan sebagai akibat dan kemajuan pembangunan ekonomi. ${ }^{4}$

Oleh karena itu dibutuhkan suatu ketentuan yang dapat menampung kebutuhan masyarakat dalam kemajuan pembangunan ekonomi. Lahirnya UndangUndang tentang hak tanggungan merupakan pelaksanaan dari ketentuan Pasal 51 Undang-Undang Nomor 5 tahun 1960 tentang Peraturan Dasar Pokok-Pokok Agraria (selanjutnya disebut UUPA) yang menyebutkan bahwa "hak tanggungan yang dapat dibebankan pada hak milik, hak guna usaha, dan hak guna bangunan tersebut dalam Pasal 25, Pasal 33 dan Pasal 39 diatur dalam undang-undang. Tetapi Pasal 57 UUPA menyebutkan bahwa selama undang-undang hak tanggungan belum terbentuk maka digunakan ketentuan tentang hipotek sebagaimana diatur dalam KUHPerdata dan Credietverband.

Perintah ketentuan Pasal 51 UUPA baru diwujudkan setelah 36 tahun UUPA berlaku, dengan lahirnya Undang-Undang Hak Tanggungan yang ditetapkan pada tanggal 9 April 1996, Undang-Undang ini terdiri atas 2 bab dan 31 pasal. Kehadiran undang-undang tersebut dimaksudkan sebagai pengganti hipotek dan credietverband, dengan demikian perikatan objek jaminan utang berupa tanah sepenuhnya dilakukan melalui lembaga jaminan hak tanggungan, sebagaimana disebutkan dalam Pasal 1 angka 1 undang-undang tersebut yang menyatakan bahwa hak tanggungan merupakan hak jaminan yang dibebankan pada hak atas tanah sebagaimana dimaksud dalam Undang-Undang No. 5 tahun 1960, berikut atau tidak berikut benda-benda lain yang merupakan satu kesatuan dengan tanah itu, untuk perluasan utang tersebut yang memberikan kedudukan yang diutamakan kepada kreditur tertentu terhadap kreditur lain. Namun demikian mengingat ketentuan Pasal 51 UUPA yang hanya menyebutkan bahwa hak tanggungan yang dapat dibebankan pada hak milik, hak guna usaha, hak guna bangunan, dapat menimbulkan permasalahan, dengan adanya perkembangan dan kemajuan pembangunan ekonomi.

\footnotetext{
${ }^{4}$ St. Remy Sjahdewi, Hak Tanggungan, Azas, Ketentuan-ketentuan Pokok dan Masalah yang dihadapi oleh Perbankan (suatu kajian mengenai undang-undang hak tanggungan,Bandung: Alumni, 1999, hal. 2-3.
}

\section{PERMASALAHAN}

1. Apakah hak pakai atas tanah dapat dipergunakan sebagai jaminan utang dengan dibebani hak tanggungan.

2. Apakah hak tanggungan dapat dibebankan kepada bangunan-bangunan di atas tanah yang berbeda kepemilikannya.

\section{TUJUAN PENULISAN}

1. Untuk mengetahui apakah hak pakai atas tanah dapat dipergunakan sebagai jaminan utang dengan dibebani hak tanggungan

2. Apakah hak tanggungan dapat dibebankan kepada bangunan-bangunan di atas tanah yang berbeda kepemilikannya.

\section{HAK PERORANGAN ATAS TANAH}

Hak perorangan atas tanah adalah hak yang memberi wewenang kepada pemegang haknya (perorangan, sekelompok orang, secara bersama-sama, badan hukum) untuk memakai, dalam arti menguasai, menggunakan dan/atau mengambil manfaat dari tanah tertentu. ${ }^{5}$

Dalam pengertian yuridis menurut UUPA, tanah adalah permukaan bumi, sedangkan hak atas tanah adalah hak atas permukaan bumi yang berbatas, berdimensi dua dengan ukuran panjang dan lebar. Selanjutnya hak atas tanah adalah hak yang untuk menggunakan tanah dan/atau mengambil manfaat dari tanah yang dihakikinya. Perkataan menggunakan mengandung pengertian bahwa hak atas tanah itu digunakan untuk kepentingan bangunan (non pertanian) sedangkan perkataan mengambil "manfaat" mengandung pengertian bahwa hak atas tanah itu digunakan untuk kepentingan bukan mendirikan bangunan, melainkan untuk kepentingan pertanian, perikatan, peternakan, dan perkebunan.

Pasal 4 ayat (1) UUPA mengatur tentang pemberian hak atas tanah kepada perorangan, yang menyebutkan bahwa: "atas dasar hak menguasai dari negara sebagai yang dimaksud dalam Pasal 2 (bumi, air dan ruang angkasa, termasuk kekayaan alam yang terkandung di dalamnya itu pada tingkatan terting-gi dikuasai oleh negara sebagaimana organisasi ke-

\footnotetext{
5 Urip Santoso, Hukum Agraria Kajian Komprehensif, Jakarta,:Kencana Prenada Media Group, 2012, hal. 83.
} 
kuasaan seluruh rakyat) ditentukan adanya macammacam hak atas permukaan bumi, yang disebut tanah yang dapat diberikan kepada dan dipunyai oleh orang-orang, baik sendiri maupun bersama-sama dengan orang-orang lain serta badan-badan hukum.

Macam-macam hak atas tanah diatur dalam ketentuan Pasal 16 ayat (1), Pasal 53 UUPA, dan Peraturan Pemerintah Nomor 40 Tahun 1996 tentang Hak Guna Usaha, Hak Guna Bangunan dan Hak Pakai atas Tanah, yang meliputi hak-hak atas tanah yang bersifat tetap yaitu hak milik hak guna usaha, hak guna bangunan, hak pakai, beserta hak-hak yang bersifat sementara yaitu hak sewa, hak membuka tanah, hak memungut hasil hutan dan hak-hak lain yang tidak termasuk dalam hak-hak tersebut diatas yang akan ditetapkan dengan undang-undang.

Berikut ini akan diuraikan mengenai hak-hak atas tanah yang bersifat tetap sebagai berikut:

\section{Hak Milik}

Menurut ketentuan Pasal 20 ayat (1) UUPA adalah hak turun temurun, terkuat dan terpenuh yang dapat dipunyai orang atas tanah dengan mengingat ketentuan dalam Pasal 6 (hak atas tanah mempunyai fungsi sosial). "Turun temurun" berarti hak milik dapat berlangsung terus selama pemiliknya masih hidup dan bila pemiliknya meninggal dunia maka dapat diteruskan oleh ahli warisnya sepanjang memenuhi syarat sebagai subjek hak milik. "Terkuat", hak milik atas tanah lebih kuat jika dibandingkan hak atas tanah lainnya, tidak mempunyai batas waktu tertentu, mudah dipertahankan dari gangguan pihak lainnya serta tidak mudah dihapus. "Terpenuh", hak milik atas tanah memberi wewenang kepada pemiliknya paling luas bila dibandingkan dengan hak atas tanah yang lain, tidak berinduk pada hak atas tanah yang lain dan penggunaan tanahnya lebih luas bila dibandingkan dengan hak atas tanah lainnya.

Hak milik atas tanah dapat dimiliki oleh war- ga negara Indonesia perorangan, badan hukum ter- tentu yang ditunjuk oleh pemerintah berdasarkan Peraturan Pemerintah Nomor 38 tahun 1963 ten- tang Penunjukan,Badan-Badan Hukum yang Dapat Mempunyai Hak Milik atas Tanah seperti bank-bank pemerintah, badan sosial, badan keagaam serta koperasi pertanian. Penggunaan hak milik harus memperhatikan fungsi sosial hak atas tanah yaitu penggunaan tanah tidak boleh menimbulkan kerugian gan antara kepentingan pribadi dengan kepentingan umum, dan tanah harus dipelihara dengan baik agar bertambah kesuburan dan mencegah kerusakannya. ${ }^{6}$ Hak milik milik atas tanah merupakan hak atas tanah yang wajib didaftarkan serta menurut sifatnya dapat dipindahtangankan, sehingga dapat dibebani dengan hak tanggungan.

\section{Hak Guna Usaha}

Menurut ketentuan Pasal 28 ayat (1) UUPA adalah hak untuk mengusahakan tanah yang dikuasai langsung oleh negara. Hak guna usaha mempunyai jangka waktu paling lama 25 tahun. Untuk perusahaan yang memerlukan waktu yang lebih lama dapat diberikan waktu paling lama 35 tahun. Atas permintaan pemegang hak dan mengingat keadaan perusahaannya jangka waktunya dapat diperpanjang paling lama 25 tahun.

Pasal 8 Peraturan Pemerintah No. 40 tahun 1996 tentang Hak Guna Usaha,Hak Guna Bangunan dan Hak Pakai atas Tanah mengatur tentang jangka waktu hak guna usaha untuk pertama kalinya, paling lama 35 tahun, dapat diperpanjang untuk jangka waktu paling lama 25 tahun, dan perbaharui paling lama 35 tahun. Permohonan untuk memperpanjang atau melakukan pembaharuan harus dilakukan selambat-lambatnya 2 tahun sebelum jangka waktu hak guna usaha tersebut berakhir. Hak guna usaha untuk kepentingan penanaman modal, permintaan perpanjangan atau pembaharuan hak guna usaha dapat dilakukan sekaligus dengan membayar uang pemasukan yang ditentukan untuk itu, pada saat pertama kali mengajukan permohonan.

Hak guna usaha merupakan hak atas tanah yang wajib didaftarkan dan menurut sifatnya dapatdipindahtangankan, sehingga dapat dipergunakan sebagai jaminan utang dengan dibebani hak tanggungan. Hak guna usaha dapat dimiliki oleh warga negara Indonesia dan badan hukum yang didirikan menurut hukum Indonesia dan berkedudukan di Indonesia (Badan Hukum Indonesia).

\section{Hak Guna Bangunan}

Hak Guna Bangunan diatur dalam ketentuan Pasal 35 sampai dengan 40 UUPA. Pasal 50 ayat (2) UUPA menyebutkan bahwa ketentuan lebih lanjut mengenai hak guna bangunan akan diatur dengan

bagi orang lain, penggunaan tanah harus disesuaikan dengan keadaan dan sifat haknya, adanya keseimban- 
peraturan perundangan. Peraturan perundangan yang dimaksud adalah Peraturan Pemerintah No. 40 tahun 1996 yang secara khusus diatur dalam Pasal 19 sampai dengan Pasal 38.

Pengertian hak guna bangunan sebagaimana yang disebutkan dalam ketentuan Pasal 35 UUPA adalah hak untuk mendirikan dan mempunyai bangunan atas tanah yang bukan mendirikan dan mempunyai bangunan atas tanah yang bukan miliknya sendiri, dengan jangka waktu paling lama 30 tahun dandapat diperpanjang untuk waktu 20 tahun.

Peraturan Pemerintah No. 40 tahun 1996 mengatur jangka waktu hak guna bangunan sesuai dengan asal tanahnya yaitu:

a. Jika hak guna bangunan atas tanah negara maka jangka waktu untuk pertama kali paling lama 30 tahun, dapat diperpanjang untuk waktu paling lama 20 tahun dan diperbaharui untuk waktu paling lama 30 tahun. Perpanjangan dan pembaharuannya harus diajukan selambat-lambatnya dua tahun sebelum jangka waktu berakhir. Hak guna bangunan atas tanah negara wajib didaftar, dan karena sifatnya dapat dipindahtangankan, sehingga dapat dipergunakan sebagai jaminan utang dengan dibebani hak tanggungan.

b. Hak guna bangunan atas tanah hak pengelolaan. Hak pengelolaan merupakan tanah negara yang penyelenggaraannya sebagian diserahkan kepada pihak ketiga. Hak guna bangunan atas tanah hak pengelolaan jangka waktunya untuk pertama kalinya paling lama 30 tahun, dapat diperpanjang untuk jangka waktu paling lama 20 tahun, dan dapat diperbaharui untuk jangka waktu paling lama 30 tahun. Perpanjangan ataupun pembaharuannya dilakukan atas permohonan pemegang hak guna bangunan setelah mendapat persetujuan dari pemegang hak pengelolaan, selambat-lambatnya dua tahun sebelum berakhirnya jangka waktu hak guna bangunan tersebut. Hak guna bangunan merupakan hak atas tanah yang wajib didaftarkan/dicatatkan dalam buku tanah pada Kantor Pertanahan Kebupaten/Kota setempat, sehingga karena sifatnya dapat dipindahtangankan, oleh karenanya dapat dipergunakan sebagai jaminan utang dengan dibebani hak tanggungan.

c. Hak guna bangunan atas tanah hak milik. Hak guna bangunan ini mempunyai jangka waktu untuk pertama kalinya paling lama 30 tahun, dan tidak dapat diperpanjang jangka waktunya, kecuali berdasarkan kesepakatan dengan pemilik tanah dapat diperbaharui dengan pemberian hak guna bangunan baru dengan akte yang dibuat oleh PPAT (Pejabat Pembuat Akta Tanah) dan wajib didaftarkan pada Kantor Pertanahan Kabupaten/ Kota setempat. Berdasarkan azas yang dianut oleh UUPA yang berdasarkan kepada Hukum Adat, disebutkan azas pemisahan secara horizontal yaitu pemisahan antara tanah dengan benda-benda yang ada di atasnya, maka hak guna bangunan ini dapat dipergunakan sebagai jaminan utang dengan dibebani hak tanggungan. Dengan habisnya/ lewatnya jangka waktu hak guna bangunan ini maka hapus juga hak tanggungan tersebut.

\section{Hak Pakai}

Secara khusus diatur dalam Pasal 41 sampai dengan Pasal 43 UUPA. Ketentuan hak pakai menurut Pasal 50 ayat 2 UUPA akan diatur dengan peraturan perundang-undangan. Peraturan perundang-undangan yang dimaksud adalah Peraturan Pemerintah No. 40 Tahun 1996 yang secara khusus diatur dalam $\mathrm{Pa}$ sal 39 sampai dengan Pasal 58.

Hak pakai adalah hak untuk menggunakan dan/ atau memungut hasil dari tanah yang dikuasai langsung oleh negara atau tanah milik orang lain, yagn memberi wewenang dan kewajiban yang ditentukan dalam keputusan pemberiannya oleh pejabat yang berwenang memberikannya atau dalam perjanjian dengan pemilik tanahnya yang bukan perjanjian sewa menyewa atau perjanjian pengolahan tanah, se- gala sesuatu asal tidak bertentangan dengan jiwa dan ketentuan UUPA.

Perkataan "menggunakan" dalam hak pakai diartikan bahwa hak pakai digunakan untuk kepentingan mendirikan bangunan, sedangkan kata "memungut hasil" menunjukan pengertian bahwa hak pakai dipergunakan untuk kepentingan selain untuk mendirikan bangunan misalnya, pertanian, perikanan, peternakan atau perkebunan.

Hak pakai dapat dimiliki oleh warga negara Indonesia, badan hukum yang didirikan menurut hukum Indonesia dan berkedudukan di Indonesia, badan hukum asing yang berkedudukan di Indonesia, orang asing yang berkedudukan di Indonesia.

Jangka waktu hak pakai dalam Pasal 41 ayat (2) UUPA tidak ditentukan secara tegas beberapa lama jangka waktunya. Namun Peraturan Pemerintah No. 40 Tahun 1996 jangka waktu hak pakai diatur dalam Pasal 45 sampai dengan Pasal 49 sesuai asal tanahnya yaitu: 
a. Hak pakai atas tanah negara

Hak pakai ini jangka waktunya untuk pertama kali paling lama 25 tahun, dapat diperpanjang untuk jangka waktu paling lama 20 tahun, dan dapat diperbaharui untuk jangka waktu paling lama 25 tahun. Khusus untuk hak pakai yang dimiliki departemen, lembaga pemerintah non departemen, pemerintah daerah, badan-badan keagamaan dan sosial, perwakilan negara asing, dan perwakilan badan internasional, diberikan untuk jangka waktu yang tidak ditentukan selama tanahnya digunakan untuk keperluan tertentu.

Menurut AP Parlindungan, bahwa ada hak pakai yang bersifat publikrehtelijke, yang tanpa right of dispossal (yang tidak boleh dijual ataupun dijadikan jaminan utang) yaitu hak pakai yang diberikan untuk instansi-instansi pemerintah seperti sekolah, perguruan tinggi, kantor pemerintah dan pakai yang diberikan untuk perwakilan asing yaitu hak pakai yang diberikan untuk waktu yang tidak terbatas, dan selama pelaksanaan tugasnya, ataupun hak pakai yang diberikan untuk waktu yang tidak tertentu dan selama melaksanakan tugasnya. $^{7}$

Perpanjangan atau pembaharuan hak pakai, selambat-lambatnya dua tahun sebelum hak pakai berakhir. Perpanjangan dan pembaharuan hak pakai dicatat dalam buku tanah pada kantor kabupaten/kotamadya setempat.

b. Hak pakai atas tanah pengelolaan

Jangka waktu hak pakai ini untuk pertama kali paling lambat 25 tahun, dapat diperpanjang untuk jangka waktu paling lama 20 tahun, dapat diperbaharui untuk jangka waktu paling lama 25 tahun. Perpanjangan atau pembaharuannya dapat dilakukan atas usul pemegang hak pengelolaan.

c. Hak pakai atas tanah hak milik

Hak pakai ini diberikan dengan jangka waktu paling lama 25 tahun dan tidak dapat diperpanjang kecuali atas kesepakatan antara pemilik tanah dengan pemegang hak pakai, dapat diperbaharui dengan pemberian hak pakai baru dengan akte yang dibuat oleh PPAT dan wajib didaftar pada Kantor Pertanahan Kabupaten/Kota setempat untuk dicatat dalam buku tanah.

\footnotetext{
${ }^{7}$ AP Parlindungan, Hak Pengelolaan Menurut Sistem UUPA, Ban-
} dung: Mandarmaju, 1989, Hal. 34

\section{PEMBEBANAN HAK PAKAI DENGAN HAK TANGGUNGAN}

UUPA tidak mengatur tentang hak pakai dapat dijadikan jaminan utang dengan dibebani hak tanggungan (Pasal 51 UUPA), tetapi pembebanan hak pakai dengan hak tanggungan diatur dalam Pasal 53 Peraturan Pemerintah No. 40 tahun 1996, yaitu hak pakai atas tanah negara dan hak pakai atas tanah hak pengelolaan dapat dijadikan jaminan utang dengan dibebani dengan hak tanggungan, sedangkan hak pakai atas tanah hak milik tidak dapat dijadikan jaminan utang dengan dibebani hak tanggungan. Hak tanggungan hapus dengan hapusnya hak pakai. Ketentuan ini berbeda dengan ketentuan undang-undang hak tanggungan, bahwa hak pakai yang dapat dijadikan jaminan utang dengan dibebani hak tanggungan adalah hak pakai atas tanah negara yang menurut ketentuannya wajib didaftar dan menurut sifatnya dapat dipindahtangankan. Semua hak pakai wajib didaftarkan pada Kantor Pertanahan Kabupaten/Kota setempat. Namun ada hak pakai yang tidak dapat dipindahtangankan sehingga hak dapat dibebani dengan hak tanggungan yaitu hak pakai yang dipunyai oleh departemen, lembaga pemerintah non departemen, pemerintah daerah, badan-badan keagaam dan sosial, perwakilan negara asing, dan perwakilan badan internasional, sehingga antara undang-undang hak tanggungan dengan peraturan pemerintah No. 40 tahun 1996 terdapat ketidak sinkronan yaitu undang-undang No. 4 tahun 1996 mengatur bahwa hak pakai atas tanah negara dan hak pakai atas tanah hak pengelolaan bisa dijadikan jaminan utang dengan dibebani hak tanggungan. Dari segi hierarkhi peraturan perundang-undangan maka peraturan pemerintah No. 40 tahun 1966 menyimpangi Undang-Undang No. 4 tahun 1996.

\section{HUKUM JAMINAN DI INDONESIA.}

Istilah Jaminan merupakan terjemahan daribahasa Belanda yaitu Zekerhid atau cantie, yang mencakup secara umum cara-cara kreditor menjamin di penuhinya tagihannya di samping pertanggungjawaban umum debitor terhadap barang-barangnya.

Hukum Jaminan adalah keseluruhan dari kaidahkaidah hukum yang mengatur hubungan Hukum antara pemberi dan penerima jaminan dalam kaitannya dengan pembebanan jaminan untuk mendapatkan fasilitas kredit ${ }^{8}$.

\footnotetext{
${ }^{8}$ J. Satrio, Hukum Jaminan Hak-Hak Kebendaan, Bandung: Citra Aditya Bakti, 1986, Hal 3.
} 
Perkembangan hukum Jaminan di Indonesia, sejak Pemerintahan Hindia Belanda, yang pada mulanya diatur dalam Buku II KUH Perdata meliputi hal-hal yang berkaitan dengan Pembebanan Jaminan bagi orang Bumi Putra (Indonesia asli). Hak atas tanah yang dapat di bebani credit verband adalah Hak milik, Hak Guna Bangunan (HGB), Hak Guna Usaha (HGU).

Setelah berlakunya UUPA, di dalam konsiderannua menyebutkan bahwa buku II KUHPerdata tidak berlaku lagi sepanjang mengenai Bumi, air serta kekayaan alam yang terkandung, crediet verband, sehingga terjadi dualisme secara formal pembebanan jaminan, terutama hak atas tanah ketentuan-ketentuan dalam UUPA tetapi secara materil yang berkaitan dengan hak dan kewajiban para pihak berlaku ketentuan dalam KUH Perdata Buku II dan Crediet Verband.

Dengan diundangkanya Undang-undang No. 4 tahun 1996 tentang Hak Tanggungan maka seca- ra formal dan material berlaku ketentuan-ketentuan dalam undang-undang tersebut sehingga menghapuskan dualisme dalam pembangunan jaminan.

\section{HAK TANGGUNGAN ATASTANAH}

Hak tanggungan atas tanah beserta benda yang berkaitan dengan tanah-tanah telah lahir pada 4 April 1996 melalui Undang-undang No. 4 tahun 1996 dengan demikian hak tanggungan merupakan satusatunya lembaga hak jaminan atas tanah sehingga tercapai unifikasi dalam Hukum Tanah Nasional.

Pengertian hak tanggungan sebagaimana disebutkan dalam ketentuan Pasal 1 huruf a adalah Hak jaminan yang dibebankan pada hak atas tanah sebagaimana di maksudkan dalam UUPA berikut atau tidak berikut benda benda lain yang merupakan satu kesatuan dengan tanah itu, untuk pelunasan utang tertentu, yang memberikan kedudukan yang diutamakan kepada kreditur tertentu terhadap kreditor-kreditor lain.

Dengan pengertian tersebut maka unsur-unsur hak tanggungan adalah merupakan hak jaminan untuk pelunasan hutang (kredit) dapat di bebankan pada Hak atas tanah dengan atau tanpa benda di atasnya, menimbulkan kedudukan di dahulukan dari pada kreditor lainnya.

Dengan demikian sifat-sifat hak tanggungan yaitu:

1. Tidak dapat dibagi (ondeelbaar) artinya Hak tanggungan membebani secara utuh obyeknya dan setiap bagian dari padanya pelunasan sebagian utang yang dijamin tidak membebaskan sebagian obyek dari beban hak tanggungan tapi hak tanggungan teta membebani seluruh obyeknya untuk sisa utang yang belum lunas kecuali diperjanjikan dalam akta pemberian hak Tanggungan (APHT),

2. Hak tanggungan bersifat Accessoir, hanya merupakan ikatan dari perjanjian pokok yaitu perjanjian yang menimbulkan hubungan hukum hutang piutang.

Dalam ketentuan Pasal 51 UUPA ditunjuk hakhak atas tanah yang dapat dipergunakan sebagai jaminan utama dengan dibebani hak tanggungan adalah hak milik, Hak Guna Usaha dan Hak Guna Bangunan sebagai hak-hak yang wajib didaftarkan dan menurut sifatnya dapat dipindahtangankan.

Hak pakai dalam UUPA tidak ditnjuk sebagai objek hak tanggungan, oleh karena pada saat ini hak pakai tidak termasuk hak-hak atas tanah yang wajib didaftar karenanya tidak memenuhi syarat publisitas untuk dapat dijadikan jaminan hutang.

Didalam perkembangannya, bagi para pemegang hak atas tanah yang sebagian terbesar terdiri atas gotongan ekonomi, lemahnya tidak berkemampuan untuk mempunyai tanah dengan hak milik, hak guna bangunan, hak Guna usaha, menjadi terbuka kesempatannya untuk memperoleh kredit yang diperlukan dengan menggunakan tanah yang dipunyainya sebagai jaminan, sehingga undang-undang hak tanggungan adalah, hak milik, hak guna usaha, dan hak guna bangunan sebagai hak-hak yang wajib didaftarkan dan menurut sifatnya dapat dipindahtangankan. Selama dapat dipergunakan sebagai jaminan utang dengan dibebani hak tanggungan.

Hak pakai atas tanah yang dapat dibebani hak tanggungan yaitu:

1. Hak pakai atas tanah negara yang diberikan kepada orang perorangan;

2. Hak pakai atas tanah negara yang diberikan kepada badan hukum perdata.

Kedua hak pakai tersebut merupakan hak yang wajib didaftarkan, yang menurut sifatnya dan kenyataannya dapat dipindahtangankan sehingga dapat dibebani dengan hak tanggungan. Akan tetapi hak pakai atas tanah negara yang walaupun wajib didaftarkan, karena sifatnya tidak dapat dipindahtangankan seperti hak pakai atas nama Pemerintah atas nama bandan keagamaan, badan sosial, hak pakai atas nama perwakilan negara asing yang berlakumya 
tidak ditentukan jangka waktunya dan tanahnya diberikan selama dipergunakan untuk keperluan tertentu (sehingga bukan merupakan obyek hak tanggungan). Demikian juga hak milik yang sudah diwakafkan, dan tanah-tanah yang dipergunakan untuk peribadatan dan keperluan suci lainya, walaupun didaftarkan, karena menurut sifatnya dan tujuannya tidak dapat dipindahtangankan sehingga tidak dapat dibebani dengan hak tanggungan.

Hak tanggungan menurut undang-undang ini pada dasarnya adalah hak tanggungan yang dibebankan kepada hak atas tanah, namun pada kenyataannya yang merupakan bagian dari tanah tersebut yang dipergunakan sebagai jaminan, sebagaimana diketahui Hukum Tanah Nasional berdasarkan Hukum adat yang mempergunakan asas pemisahan secara horizontal. Berdasarkan pada azas tersebut maka benda-benda yang berada di atas tanah dianggap terpisah dengan tanah, (tidak merupakan kesatuan dengan tanah) sehingga setiap perbuatan hukum meliputi benda-benda tersebut. Tapi dapat juga meliputi bendabenda di atas tanah tersebut sepanjang dengan tegas dinyatakan oleh pihak-pihak dalam akta pemberian hak tanggungan.

\section{KESIMPULAN}

1. Berdasarkan ketentuan Pasal 51 UUD, hak pakai tidak dapat dipergunakan sebagai jaminan utang dengan dibebani hak tanggungan, oleh karena hanya hak-hak yang wajib didaftarkan dan karena sifatnya dapat dipindahtangankan, yang dapat dipergunakan sebagai jamunan utang dengan dibebani rangkaian dengan berlaku Undang-Un- dang No. 4 tahun 1996, tentang HakTanggungan dan Benda-Benda yang Ada di atasnya, mengatur bahwa hak pakai merupakan hak yang wajib didaftarkan dan karena sifatnya dapat du pindah tangankan seperti hak pakai atas tanah negara yang diperuntukkan bagi perorangan dan badan hukum swasta, sehingga dapat dibebankan dengan hak tanggungan.

2. Mengingat Asas horizontal yang dianut oleh hukum adat, yang kemudian menjadi dasar berlakunya UUPA, dimana terdapat pemisahan antara tanah dengan benda-benda yang ada diatasnya, sehingga hak tanggungan pun dapat di bebankan kepada bangunan-bangunan diatas tanah yang berbeda kepemilikannya, asalkan di cantumkan dalam Akte hak tanggungan.

\section{SARAN}

1. Pemerintah agar melakukan revisi terhadap UUPA sebagai induk dari ketentuan/peraturan pertanahaan di Indonesia, agar tidak terjadi pertentangan antara UUPA dengan peraturan pemerintah lainnya;

2. Mengingat banyak sekali terjadi hak atas luas benda kepemilikannya dengen benda-benda yang ada diatasnya, karena pembebanan terhadap hakhak lainnya, maka perlu ada aturan secara khusus tuntas hal tersebut selain mengacu kepada asas Horizontal Scheiding, serta kepada masyarakat agar berhati-hati jika di atas tanahnya dibeban dengan hak atas tanah orang lain, dalam hal tanah tersebut dipergunakan sebagai jaminan utang gar dibuat perpanjang secara tegas yang dicantumkan dalam Akte hak tanggungan tersebut. 
Jurnal Hukum tô-râ, Vol. 1 No. 2, Agustus 2015

\section{DAFTAR PUSTAKA}

\section{Buku:}

AP Parlindungan, Hak Pengelolaan Menurut Sistem UUPA, Bandung: Mandar Maju, 1989.

Adrian Sutedi, Pengakuan Hak Milik Atas Tanah Menurut Undang-Undang Pokok Agraria, Jakarta: Cipta Jaya, 2006

Boedi Harsono, Undang-Undang Pokok Agraria, Sejarah Penyusunan, Isi dan Pelaksanaannya, Jakarta: Djambatan, 1971

Salim HS, Perkembangan Hukum Jaminan di Indonesia, Jakarta: PT. Raja Grafindo Persada, 2004

Sri Soedewi Masjhoen Sofwan, Hukum Jaminan di Indonesia, Pokok-Pokok Hukum dan Jaminan Perorangan, Jakarta: BPHN, Departemen Kehakiman RI, 1980

St. Remy Sjahdeni, Hak Tanggungan, Azas, Ketentuan-Ketentuan Pokok dan Masalah yang dihadapi oleh Perbankan (suatu kajian mengenai Undang-Undang Hak Tanggungan), Bandung: Alumni Bandung, 1999

Supriadi, Hukum Agraria, Jakarta: Sinar Grafika, 2007

Urip Santoso, Hukum Agraria Kajian Komprehensif, Jakarta: Kencana Prenada Media Group, 2012

\section{Undang-Undang:}

- Undang-Undang Dasar 1945

- Undang-Undang Nomor 5 tahun 1960 tentang Peraturan Dasar Pokok-Pokok Agraria

- Undang-Undang Nomor 4 tahun 1996 tentang Hak Tanggungan atas tanah beserta benda-benda yang ber- kaitan dengan tanah

Peraturan Pemerintah Nomor 40 tahun 1996 tentang Hak Guna Usaha, Hak Guna Bangunan dan Hak Pakai Atas Tanah 